\title{
Krajobraz poeksploatacyjny kamieniołomu Liban w Krakowie
}

\author{
Roksana Zarychta ${ }^{1}$
}

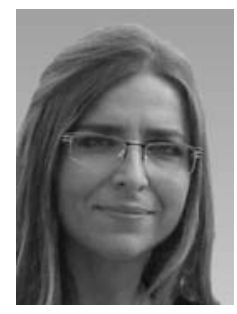

The post-mining landscape of the Liban quarry in Cracow. Prz. Geol., 67: 1002-1011; doi: 10.7306/2019.52

A b s t r a c t. The paper concerns the Liban quarry in Cracow, which is located in the Podgórze district of Cracow. It shows the outline of the geological structure and history of quarrying, while the current topography and dominant elements of the relief of this object are discussed in more detail. Anthropogenic changes in the natural environment of the quarry have revealed its geodiversity and enhanced its biodiversity. It contains vertical rocky walls, debris cones, waste-heaps, a vast undulated surface of the quarry bottom, as well as diverse flora and fauna. Within the borders of the Liban quarry, the remains of industrial buildings and the staging for the film entitled "Schindler's List" have survived. Despite the fact that the extraction has already finished a long time ago, the quarry has not been systematically reclaimed or developed.

Keywords: Liban quarry, Krzemionki Hills, Podgórze, Cracow, post-mining landscape, topography

Powszechnie uznaje się, że górnictwo odkrywkowe wywołuje negatywne zmiany w środowisku przyrodniczym, czego efektem jest m.in. niekorzystna dla dalszej działalności człowieka rzeźba terenu, a także zmienione stosunki wodne, zdegradowane gleby oraz zniszczona szata roślinna. Do najbardziej spektakularnych form rzeźby terenu na tego typu obszarach należą rozległe wyrobiska obrzeżone stromymi skarpami, a nawet ścianami skalnymi, hałdy powstałe wskutek odkrywkowej eksploatacji surowców skalnych oraz poeksploatacyjne akweny wodne. Przekształcenia w lokalnym środowisku przyrodniczym wywołane tą formą działalności człowieka są szczególnie widoczne na terenie miast, zwłaszcza jeśli są zlokalizowane w obrębie lub w sąsiedztwie ich centralnych dzielnic. Opinie mieszkańców dotyczące tak dużych przeobrażeń w środowisku przyrodniczym są zróżnicowane.

Liczne formy antropogeniczne, powstałe w wyniku prowadzenia w przeszłości odkrywkowej działalności górniczej znajdują się na terenie Krakowa. Można do nich zaliczyć m.in. kamieniołomy, glinianki oraz żwirownie. Jednymi z najtrwalszych form są wyrobiska po dawnych kamieniołomach i hałdy pogórnicze. W Krakowie znajduje się 15 dużych wklęsłych form terenu w miejscu nieczynnych kamieniołomów (Walendowski, 2005), głównie w prawobrzeżnej części miasta, gdzie dominującym elementem krajobrazu naturalnego są wzgórza zrębowe zbudowane z wapieni jurajskich (Rajchel, 2005). Jednym z najwięk- szych wyrobisk poeksploatacyjnych w tej części Krakowa jest dawny kamieniołom wapieni Liban, położony w dzielnicy Podgórze (ryc. 1). Mimo że wyrobisko nie zostało zagospodarowane dla celów turystycznych i rekreacyjnych, to stanowi cenny obiekt pogórniczy, który budzi duże zainteresowanie zarówno ze względu na wartości przyrodnicze, jak i historyczne. To właśnie tutaj w 1993 r. nakręcono niektóre sceny z filmu w reżyserii Stevena Spielberga pt. Lista Schindlera.

Niewiele publikacji odnosi się w szerszym zakresie do kamieniołomu Liban. Budowa geologiczna i rzeźba terenu tego obiektu oraz jego otoczenia przedstawiona na tle całego obszaru Krakowa stanowiła przedmiot publikacji Tyczyńskiej (1968a, b), Gradzińskiego (1972), Tyczyńskiej i Chmielowca (1988) (ryc. 2), Rutkowskiego (1992, 1993) oraz Rajchla (2005). O budowie geologicznej kamieniołomu Liban pisała Szczepańska $(2005 \mathrm{a}, \mathrm{b})$ oraz Majer-Durman (2012). Przyrodę żywą tego wyrobiska uwzględnili w swoich pracach: Salwiński (2004), Dubiel i Gawroński (2005), Gawroński (2005), Guzik i Pacyna (2005), Kotońska (2005), Walasz (2005), Walendowski (2005), Zyśk (2005), Doległo (2011), Mydłowski (2016), Bobek i Kumańska-Dziób (2018). Należy także wskazać publikacje związane z zagospodarowaniem rekreacyjnym lub turystycznym tego obszaru (Ostręga, 2001, 2002; Wicher i in., 2003; Wielgus i in., 2003; Kasztelewicz, 2010; Mydłowski, 2016). Niedawno pojawiły się prace

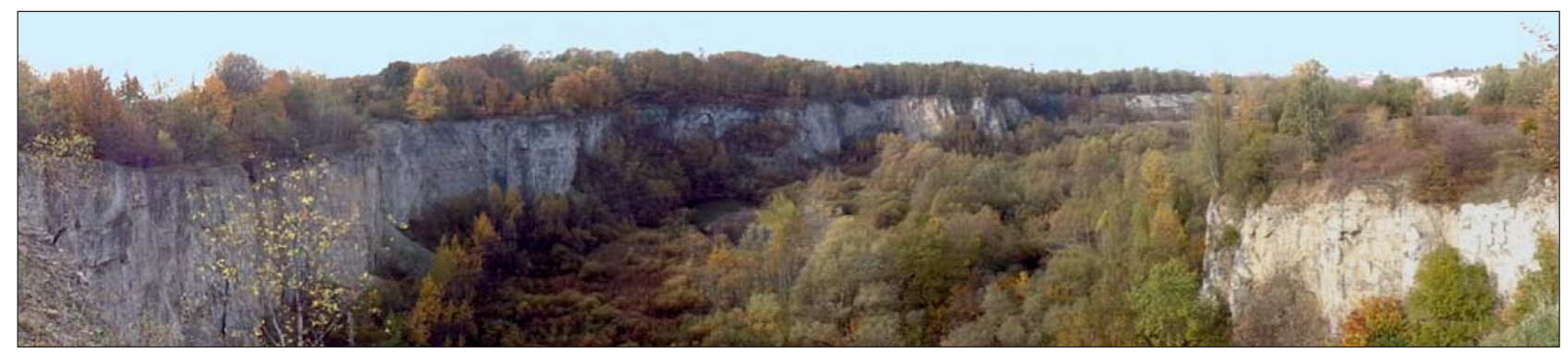

Ryc. 1. Kamieniołom Liban, widok w kierunku północnym (19.10.2019)

Fig. 1. Liban quarry, the view towards the north (19.10.2019)

\footnotetext{
${ }^{1}$ Katedra Geoinformacji i Badań Geośrodowiskowych, Instytut Geografii, Wydział Nauk Ścisłych i Przyrodniczych, Uniwersytet Pedagogiczny w Krakowie, ul. Podchorążych 2,30-084 Kraków; roksana.zarychta@up.krakow.pl
} 


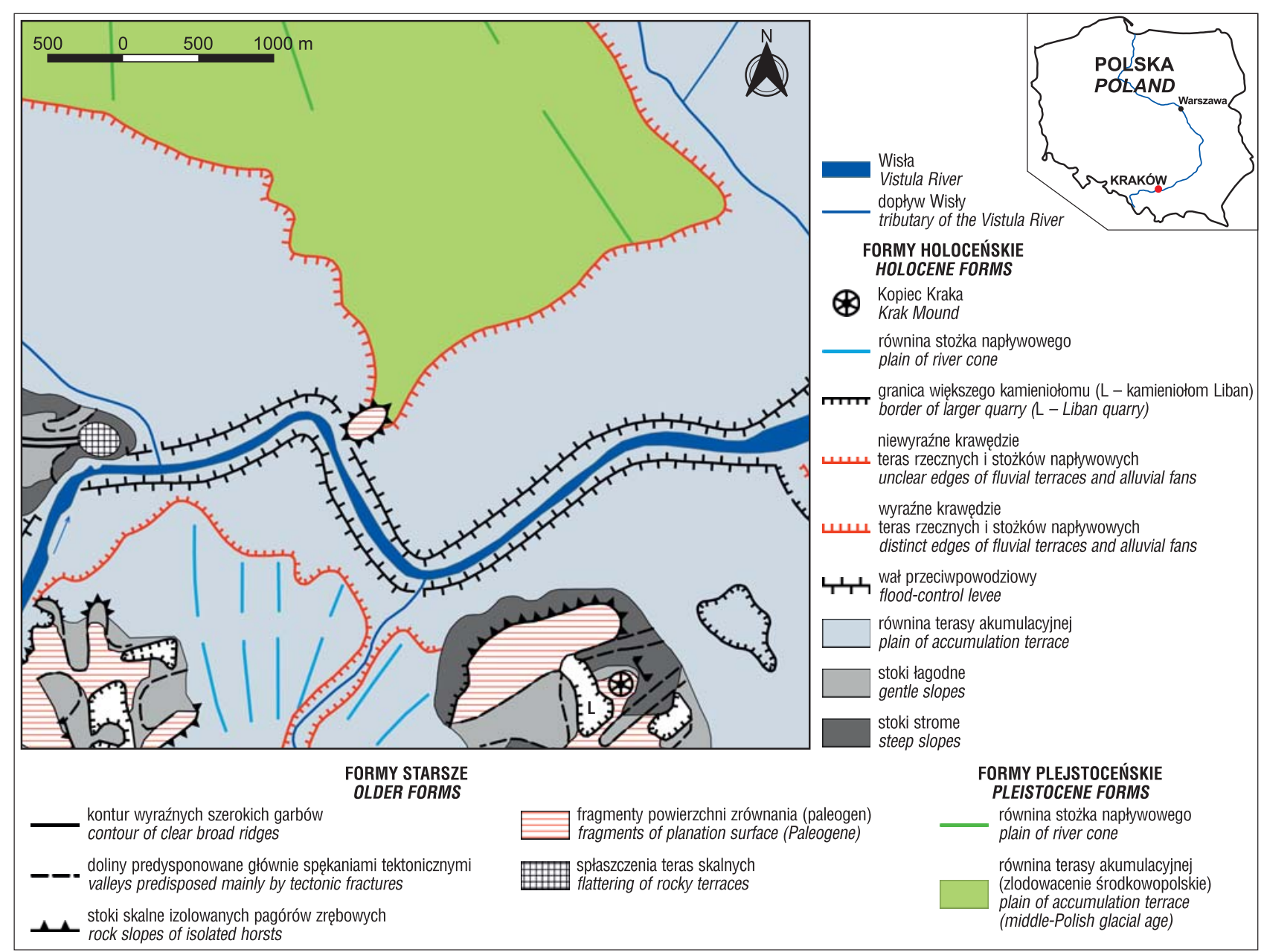

Ryc. 2. Lokalizacja kamieniołomu Liban na tle głównych form rzeźby terenu w centrum Krakowa (Tyczyńska, 1968a, b; Tyczyńska, Chmielowiec, 1988, zmodyfikowane)

Fig. 2. Location of the Liban quarry against the background of main landforms in the Cracow centre (Tyczyńska, 1968a, b; Tyczyńska, Chmielowiec, 1988, modified)

dotyczące rewitalizacji (Gliniak, 2012; Witek i in., 2014) oraz propozycji dydaktycznego wykorzystania wyrobiska Liban (Wicher i in., 2013; Gliniak, 2015; Mydłowski, 2016; Jakubowski, Kajzer-Bonk, 2017). Do opracowań zawierających ważne z punktu widzenia tematyki niniejszego artykułu informacje o kamieniołomie Liban należy zaliczyć archiwalne dokumentacje tego obiektu (Barburska, 1976; Jakubowicz i in., 1987), jak również najnowszą publikację autorki (Zarychta, 2018).

Celem pracy jest scharakteryzowanie krajobrazu poeksploatacyjnego kamieniołomu Liban w Krakowie, ze szczególnym uwzględnieniem jego aktualnej topografii oraz dominujących elementów rzeźby terenu, a także zasugerowanie sposobów jego udostępnienia i ochrony.

\section{MATERIALY I METODY BADAŃ}

Na potrzeby przygotowania niniejszego artykułu przestudiowano dostępną literaturę oraz materiały kartograficzne odnoszące się do kamieniołomu Liban. Podczas zwiadów terenowych (2018 i 2019 r.) zgromadzono dokumentację fotograficzną.

W celu przeprowadzenia analiz topograficznych odnoszących się do kamieniołomu Liban wygenerowano numeryczny model terenu (NMT) z chmury punktów z lotniczego skanowania laserowego (LiDAR) w oprogramowaniu ArcGIS 10.6.1. Z uzyskanego NMT, w SAGA GIS
6.2.0 policzono trzy najważniejsze indeksy topograficzne: analytical hillshading, slope, aspect. W programie Surfer 12 wygenerowano ryciny końcowe, prezentujące: wysokość bezwzględną oraz wymienione indeksy topograficzne w odniesieniu do badanego wyrobiska oraz terenów otaczających (ryc. 10-13). Ryciny 2, 3, 4 i 6 przygotowano w programie QGIS 2.18.25.

\section{POLOŻENIE I BUDOWA GEOLOGICZNA KAMIENIOLOMU}

Według najnowszej regionalizacji fizycznogeograficznej Polski Solona i in. (2018) kamieniołom Liban znajduje się w mezoregionie Pomost Krakowski (512.33), który należy do makroregionu Brama Krakowska (ryc. 3), podprowincji Podkarpacie Północne, prowincji Karpaty Zachodnie z Podkarpaciem Zachodnim i Północnym.

Kamieniołom Liban nazywany również Za Torem i Łom Libana (Rajchel, 2005) jest zlokalizowany w XIII dzielnicy Krakowa - Podgórzu, w północnej części grupy wzgórz o nazwie Krzemionki Podgórskie. Od północy ogranicza go ul. Za Torem i ul. Powstańców Śląskich, od północnego wschodu Kopiec Kraka (usypany w VII w.), od wschodu kamieniołom sąsiaduje on z Cmentarzem Podgórskim, od zachodu z ul. Swoszowicką (ryc. 4). Na południe od omawianej odkrywki znajduje się teren niemieckiego nazistowskiego obozu koncentracyjnego Płaszów z okresu 


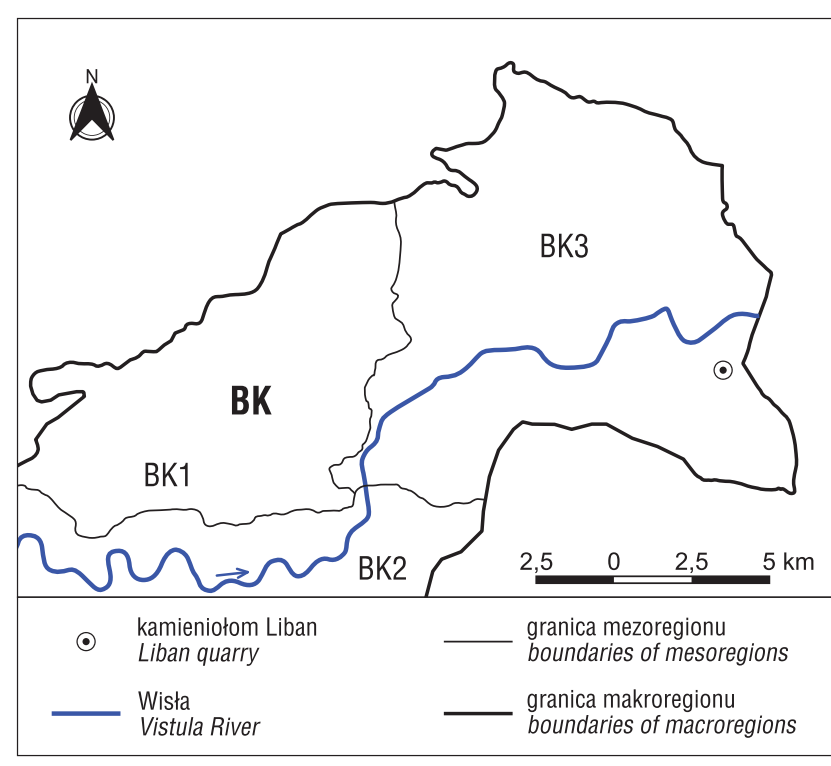

Ryc. 3. Lokalizacja kamieniołomu Liban na tle zasięgu Bramy Krakowskiej (BK). BK1 - Obniżenie Cholerzyńskie, BK2 - Rów Skawiński, BK3 - Pomost Krakowski (Solon i in., 2018, zmodyfikowane)

Fig. 3. Location of the Liban quarry at the background of Cracow Gate (BK). BK1 - Cholerzyńskie Depression, BK2 - Skawina Graben, BK3 - Cracow Landbridge (Solon et al., 2018, modified)

II wojny światowej. Ten nieczynny kamieniołom jest oddalony o 2,5 km (w linii prostej) w kierunku SE od Wawelu (ryc. 5). Jego lokalizację zaznaczono na mapach geomorfologicznych Krakowa (Tyczyńska, 1968a, b; Tyczyńska, Chmielowiec, 1988) (ryc. 2).

W kamieniołomie Liban odsłaniają się górnojurajskie wapienie skaliste $\mathrm{i}$ ławicowe $\mathrm{z}$ krzemieniami, a w dolnej części profilu - wapienie płytowe środkowego i górnego oksfordu (Rutkowski, 1992, 1993) (ryc. 6). W ścianach obserwuje się wyraźne pionowe spękania ciosowe i połogie płaszczyzny międzyławicowe. W wapieniach, oprócz różnokształtnych krzemiennych buł, są również widoczne skamieniałości. Warstwy wapieni mają antyklinalne ułożenie, w północnej części kamieniołomu zapadają na północ, a $\mathrm{w}$ południowej części na południe (Jakubowicz i in.,

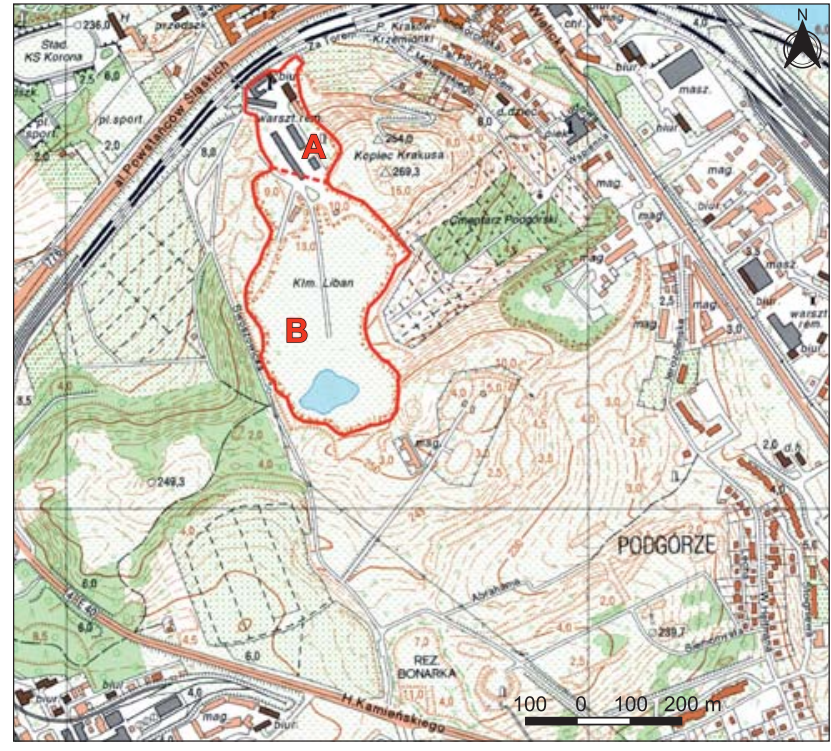

Ryc. 4. Położenie kamieniołomu Liban na mapie topograficznej (linia czerwona ciagła - granica wyrobiska, linia czerwona przerywana - linia podziału wyrobiska na część A i B, objaśnienia w tekście) (Mapa topograficzna w skali $1: 10$ 000, 1997, uzupełnione)

Fig. 4. Location of the Liban quarry on a topographic map (red line - boundary of the quarry, red dashed line - division of the quarry into parts $\mathrm{A}$ and $\mathrm{B}$, explanations in the text) (Topographic map at the scale $1: 10000,1997$, supplemented by)

1987). Po południowej stronie wyrobiska na wapieniach leżą górnokredowe zlepieńce (cenoman) oraz margle i opoki, miejscami z czertami (senon). W otoczeniu kamieniołomu na wapieniach zalegaja niewielkie płaty plejstoceńskich piasków ze zlodowacenia południowopolskiego (Rutkowski, 1992, 1993). Od wschodu i zachodu wyrobisko Libanu ograniczają antropogeniczne nasypy (ryc. 6). Wapienie jurajskie w strefie przypowierzchniowej występują na tym obszarze w zrębach tektonicznych. Wynika to z położenia kamieniołomu w strukturach zrębowych Krzemionek Podgórskich (Rutkowski, 1986, 1993).

Pomimo wieloletniego użytkowania kamieniołomu Liban nie została opracowana szczegółowa dokumentacja geologiczna tego obiektu górniczego. Jedyna ekspertyza

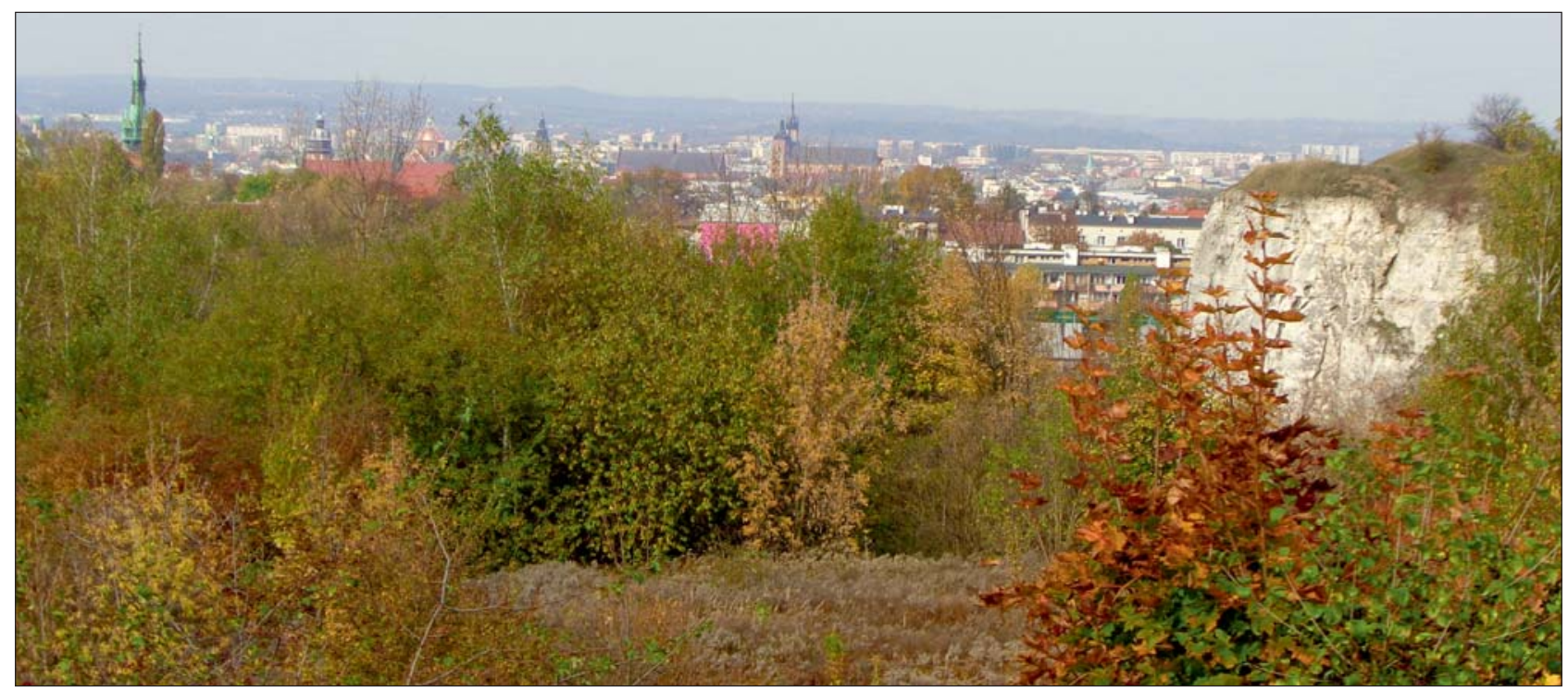

Ryc. 5. Widok na ścianę skalną El Pułkownik w kamieniołomie Liban (po prawej stronie), w głębi kościół Mariacki (19.10.2019)

Fig. 5. The view of a rocky wall called El Pułkownik in the Liban quarry (on the right), Church of Our Lady in the background (19.10.2019) 


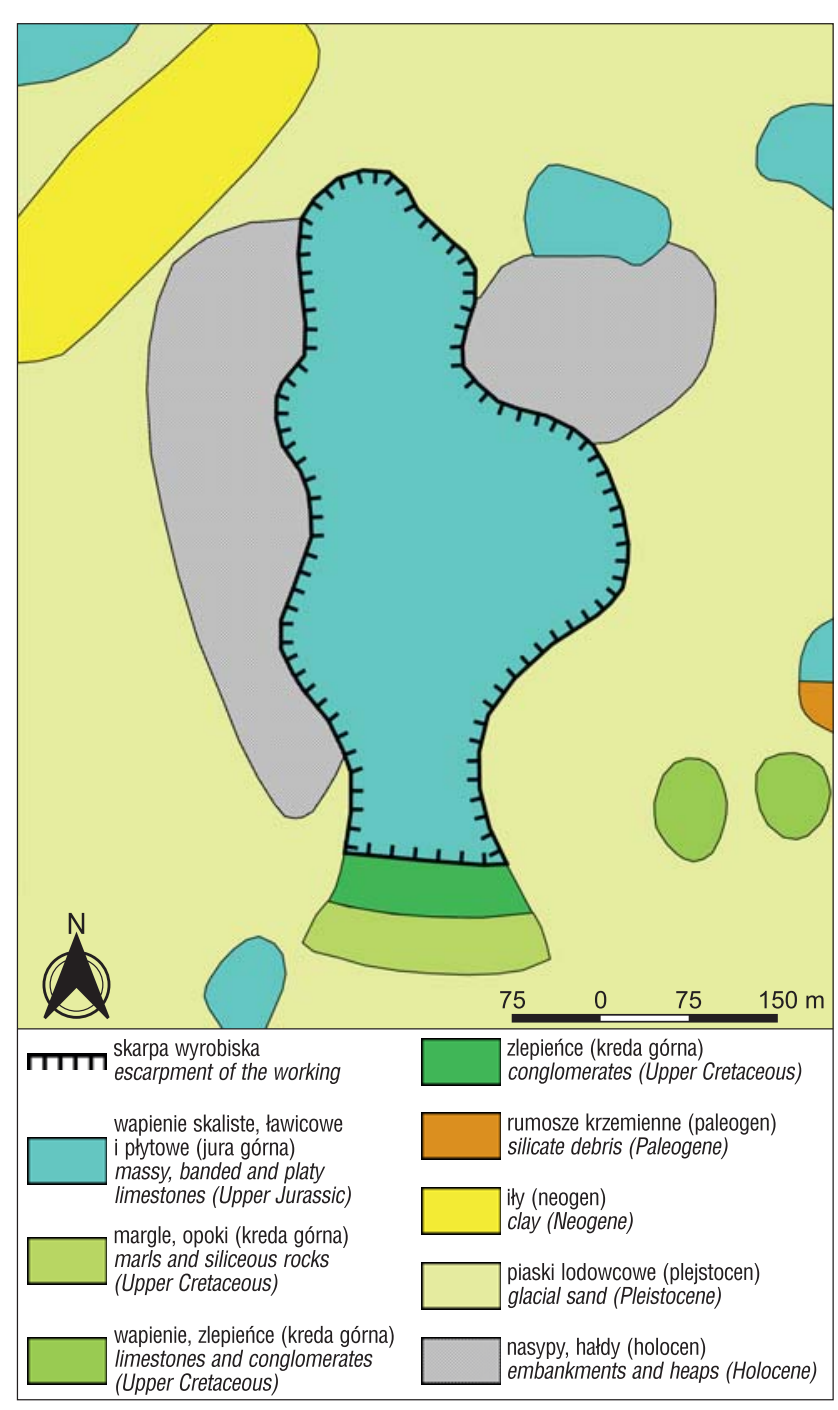

Ryc. 6. Budowa geologiczna kamieniołomu Liban i otoczenia (zarys wyrobiska pokazuje stan przed zakończeniem eksploatacji - przed 1986 r.) (Rutkowski, 1992, zmodyfikowane)

Fig. 6. Geology of the Liban quarry and its surrounding (the shape of the working shows the state before the end of extraction before 1986) (Rutkowski, 1992, modified)

wykonana przez Tokarskiego w 1951 r. wskazywała na zasoby złóż możliwe w tym czasie do wydobycia w ilości ok. 8 mln t (Jakubowicz i in., 1987). Właściwości fizyczno-mechaniczne wapienia w omawianym kamieniołomie zbadał Tyrowicz (1977), wyniki tych badań zostały opublikowane przez Szczepańską (2005b) (tab. 1).

\section{EKSPLOATACJA WAPIENI W KAMIENIOLOMIE LIBAN}

Eksploatację wapieni w kamieniołomie Liban rozpoczęto w 1873 r. (w miejscu dawnych kamieniołomów czynnych od XIV w.). Wówczas krakowski przedsiębiorca Bernard Liban wraz z Maxem Ehrenpreisem założyli firmę Kamieniołomy $i$ wapienniki Libana i Ehrenpreisa, która zajmowała się produkcją wapna budowlanego, a także nawozowego, jak również kamienia łamanego fundamentowego oraz brukowego (Górecki, Sermet, 2010).

Pod koniec XIX w. firma ta była uznawana za najważniejszą w branży materiałów budowlanych na terenie Krakowa. Wówczas dzieliła rynek zbytu z Kamieniołomami
Tab. 1. Właściwości fizyczno-mechaniczne wapienia wydobywanego w kamieniołomie Liban (Szczepańska, 2005b za Tyrowicz, 1977, zmodyfikowane)

Table 1. Physico-mechanical properties of the limestone extracted in the Liban quarry (Szczepańska, 2005b acc. to Tyrowicz, 1977, modified)

\begin{tabular}{|c|c|c|c|}
\hline $\begin{array}{l}\text { Wlaściwości fizyczno-mechaniczne } \\
\text { Physical and mechanical properties }\end{array}$ & \multicolumn{2}{|c|}{$\begin{array}{c}\text { Wartość } \\
\text { [jednostka] } \\
\text { Value [unit] }\end{array}$} & $\begin{array}{c}\text { Uwagi } \\
\text { Comments }\end{array}$ \\
\hline $\begin{array}{l}\text { Ciężar właściwy } \\
\text { Specific weight }\end{array}$ & 2,69 & \multirow{2}{*}[\mathrm{G}/\mathrm{cm}^{3}]{} & - \\
\hline $\begin{array}{l}\text { Ciężar objętościowy } \\
\text { Bulk density }\end{array}$ & 2,28 & & - \\
\hline $\begin{array}{l}\text { Porowatość } \\
\text { Porosity }\end{array}$ & 15,25 & \multirow{2}{*}[\%]{} & - \\
\hline $\begin{array}{l}\text { Nasiakkliwość wagowa } \\
\text { Weight absorption }\end{array}$ & 6,85 & & - \\
\hline $\begin{array}{l}\text { Mrozoodporność } \\
\text { Frost resistance }\end{array}$ & \multicolumn{2}{|c|}{-} & $\begin{array}{l}\text { całkowita } \\
\text { total }\end{array}$ \\
\hline $\begin{array}{l}\text { Łupliwość } \\
\text { Cleavage }\end{array}$ & \multicolumn{2}{|c|}{-} & $\begin{array}{l}\text { częściowa } \\
\text { partial }\end{array}$ \\
\hline $\begin{array}{l}\text { Wytrzymałość na ściskanie } \\
\text { Compressive strength }\end{array}$ & 60 & {$[\mathrm{MPa}]$} & $\begin{array}{l}\text { suchy } \\
\text { dry }\end{array}$ \\
\hline $\begin{array}{l}\text { Ścieralność } \\
\text { Friability }\end{array}$ & 0,99 & {$[\mathrm{~cm}]$} & $\begin{array}{c}\text { tarcza } \\
\text { Boehmego } \\
\text { Boehme } \\
\text { shield }\end{array}$ \\
\hline
\end{tabular}

i Wapiennikami Miejskimi, zlokalizowanymi w różnych rejonach Podgórza. W latach 1928-1941 r. zakłady działały jako Krakowskie Wapienniki i Kamieniołomy S.A. w Krakowie (Górecki, Sermet, 2010). Ich ponowne uruchomienie miało miejsce podczas okupacji niemieckiej w kwietniu 1942 r. Zarząd powierniczy został wówczas przekazany kierownictwu Służby Budowlanej (Baudienst). W granicach kamieniołomu Libanu z inicjatywy okupantów hitlerowskich powstał obóz Służby Budowlanej (Das Straflager des Baudienstes im General Gouvernement, S-Lager Krakau, Straflager) (ryc. 7). Jego powstanie było ściśle związane z organizacją pracy - Służba Budowlana. Latem 1944 r. karny obóz Służby Budowlanej został zlikwidowany (Wroński, 1981). Po zakończeniu II wojny światowej zakład w dalszym ciągu działał $w$ ramach różnych struktur zarówno przemysłu wapienniczego, jak i cementowego (Górecki, Sermet, 2010).

W 1960 r. utworzono obszar górniczy Krzemionki, do którego należał kamieniołom Liban oraz tereny sąsiednie.

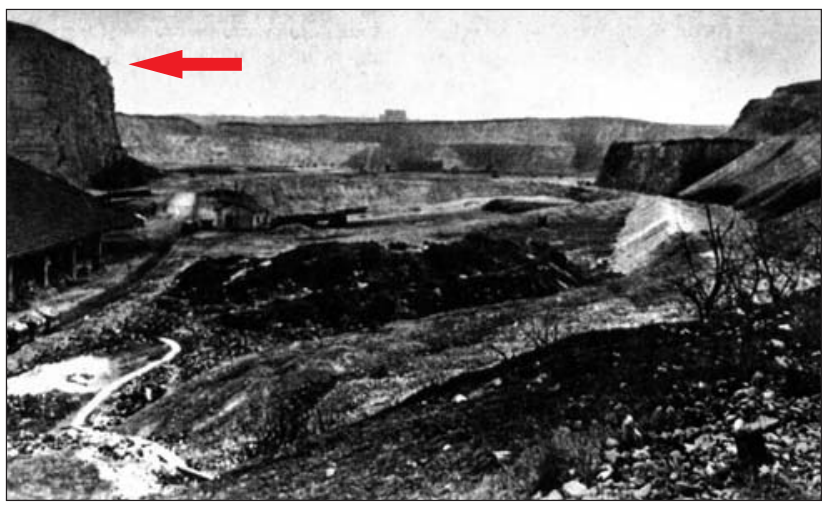

Ryc. 7. Kamieniołom Liban na początku lat 40. XX w. (po lewej stronie widok na ścianę skalną El Pułkownik) (Wroński, 1981) Fig. 7. Liban quarry in the beginning of the 1940s (on the left the view of the rocky wall El Pułkownik) (Wroński, 1981) 
Wydobycie wapieni prowadził wówczas Krakowski Kombinat Cementowo-Wapienniczy - Cementownia Nowa Huta. Eksploatacja była rozwijana w kierunku południowym i zachodnim, systemem ścianowym. Urabianie złoża prowadzono z wykorzystaniem materiałów wybuchowych. Wydobytą kopalinę przewożono do zakładu przeróbczego, a odpady z przeróbki mechanicznej gromadzono na zwałowisku zewnętrznym, skąd były zabierane i wykorzystywane na cele budownictwa drogowego (Jakubowicz i in., 1987).

Wydobycie wapieni w kamieniołomie Liban zakończono 30 czerwca 1986 r. Od tego czasu w granicach złoża pozostało jeszcze 2248 tys. t zasobów wapieni, przydatnych do produkcji wapna palonego (Jakubowicz i in., 1987). Jako ostatnią eksploatowano ścianę południowo-zachodnią (Szczepańska, 2005a, b) (ryc. 14).

\section{TOPOGRAFIA WYROBISKA GÓRNICZEGO}

Wyrobisko górnicze Liban zajmuje obecnie powierzchnię 13,2 ha. Rozciagga się na odcinku $730 \mathrm{~m}$ w kierunku $\mathrm{N}-\mathrm{S}$ i $330 \mathrm{~m}$ w kierunku W-E (uwzględniając najdalej wysunięte punkty). Obszar ten można podzielić na dwie części:

- północną (A) o powierzchni 2,4 ha (ryc. 4), gdzie początkowo rozpoczęto wydobywanie wapieni (lokalnie już w XIV w.), o dnie na wysokości 220,0-223,0 m n.p.m. obrzeżonym ścianami wysokimi skalnymi, lokalnie do ponad 20,0 m. W tej części wyrobiska górniczego zachowały się zabudowania dawnego przedsiębiorstwa górniczego;

- południową (B) o powierzchni 10,8 ha (właściwa część wyrobiska o kształcie ziarna fasoli) (ryc. 4), ukształtowaną w latach 1873-1986 podczas głównej fazy wydobywania wapieni. Dno tej części wyrobiska jest dwupoziomowe: poziom górny jest położony na wysokości 222-226 m n.p.m., a dolny na wysokości 212-214 m n.p.m., przy czym poziom górny zajmuje tylko $15 \%$ powierzchni całej odkrywki i jest widoczny jako wąska listwa (półka skalna) w NW i NE części odkrywki. Ściany skalne obrzeżające tę część wyrobiska mają wysokość do 20,0-30,0 m ponad górny poziom dna wyrobiska, a pod Kopcem Kraka na 40,0 m ponad dolny poziom dna wyrobiska (w tej części wyrobiska ściany są dwupoziomowe, ryc. 8 - patrz str. 1020). W południowej części kamieniołomu ściany skalne wznoszące się bezpośrednio ponad dolny poziom mają wysokość do 35,0 m i są najbardziej efektowne (ryc. 10, 11, 14). To w tej części kamieniołomu najpóźniej zakończono eksploatację wapieni (1986 r.).

Granicę między częściami A i B wyrobiska górniczego poprowadzono $\mathrm{w}$ jego przewężeniu w miejscu występu ściany skalnej o przyjętej już nazwie El Pułkownik u podnóża Kopca Kraka (ryc. 4, 7, 9).

Profil N-S dna wyrobiska górniczego ma typowe cechy kamieniołomu stokowo-wgłębnego. Lokalnie występujące dno poziomu górnego w części B wyrobiska jest wzniesione średnio 10,0 m wyżej niż poziom dolny, co stanowi urozmaicenie topografii omawianego obszaru. Wierzchowina wzgórza zrębowego wznosi się na tym obszarze w kierunku południowym od 230,0 m n.p.m. i w rejonie lokalnej kulminacji w sąsiedztwie Kopca Kraka osiąga 255,0 m n.p.m. Dalej na południe w sąsiedztwie części B wyrobiska górniczego (po zachodniej stronie Cmentarza Podgórskiego) maleje do 240,0 m n.p.m., a jeszcze dalej na południe ponownie zwiększa się do 256,0 m n.p.m. W efekcie wyso-

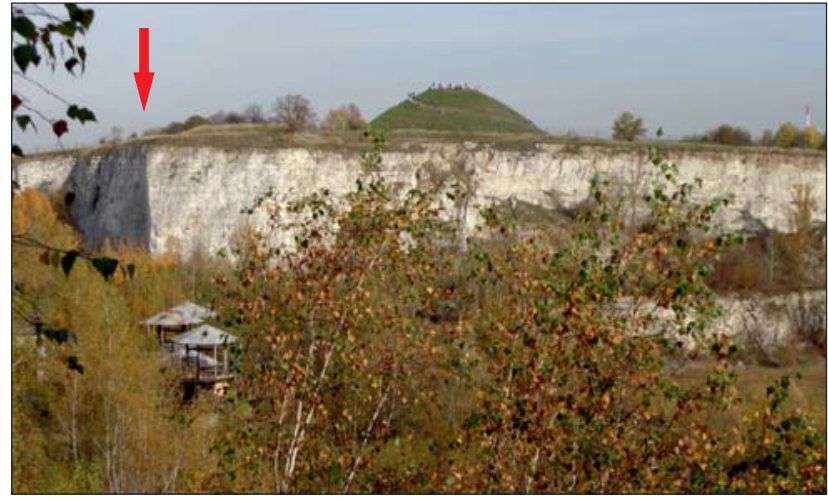

Ryc. 9. Ściana skalna El Pułkownik i miejsce jej załomu, na dalszym planie Kopiec Kraka (19.10.2019)

Fig. 9. Rocky wall El Pułkownik and the place of its curve, Krak Mound in the background (19.10.2019)

kość ścian skalnych po wschodniej stronie wyrobiska najpierw rośnie - począwszy od części A w kierunku południowym od kilku do ponad $20,0 \mathrm{~m}$, by po zachodniej stronie kulminacji pagóra z Kopcem Kraka zwiększyć się do 40,0 m (ściana podwójna), a dalej na południe zmaleć do nieco ponad 20,0 m, i jeszcze dalej na południe ponownie wzrosnąc do 35,0 m (ryc. 10,11).

Dno południowego segmentu wyrobiska górniczego obejmuje prawie poziomo położony obszar, lekko nachylony w kierunku zachodnim. W południowo-zachodniej jego części, bezpośrednio u podnóża ścian skalnych, w lokalnych płytkich zagłębieniach w obrębie dna wyrobiska, występują stałe zbiorniki wodne (ryc. 14, 17).

Główną zmianą w topografii obszaru powstałą w wyniku utworzenia wyrobiska kamieniołomu Liban jest lokalny wzrost deniwelacji, które w obrębie pasa terenu o szerokości ok. 10,0 m, obejmującym skarpy wyrobiska i przyległe obszary przekraczają 30,0 m i miejscami dochodzą do 40,0 m. Ta sytuacja kontrastuje z prawie poziomym dnem w części B wyrobiska (nawiązującym do uławicenia warstw wapienia) o lokalnych deniwelacjach do 2,0 m. Poza zasięgiem omawianego wyrobiska górniczego, np. w otoczeniu Kopca Kraka, deniwelacje na tak niewielkich obszarach wynoszą zwykle kilka metrów. Utworzenie rozległego wyrobiska górniczego doprowadziło więc do skrajnego zróżnicowania lokalnych deniwelacji - od minimalnych wielkości typowych dla prawie poziomych obszarów do pionowych ścian skalnych.

Skutkiem utworzenia omawianego wyrobiska jest zwiększenie zasięgu urwistych stoków pochodzenia antropogenicznego w obrębie Krzemionek Podgórskich. Formy takie występują w innych kamieniołomach (np. w Zakrzówku), a także na obszarach nie objętych dawną eksploatacją górniczą (np. ściany skalne wzgórza w Tyńcu z Opactwem Benedyktynów, wzgórza nad Przegorzałami, zachodni stok Wzgórza Wawelskiego). Na wymienionych obszarach nachylenia ścian skalnych są większe od $30^{\circ}$ i niekiedy osiagają $70-90^{\circ}$, np. ściany skalne obrzeżające wyrobisko kamieniołomu Liban. Kontrastuje to z minimalnym nachyleniem dna tego wyrobiska, gdzie na większości obszaru nachylenia nie przekraczają $4^{\circ}$. Także poza zasięgiem kamieniołomu Liban, np. w otoczeniu Kopca Kraka, nachylenia stoków wynoszą od kilku do kilkanastu stopni (ryc. 12).

Wyrobisko górnicze Liban jest zorientowane w kierunku N-S, więc ściany skalne mają dominującą ekspozycję wschodnią i zachodnią oraz w niewielkim stopniu północną 


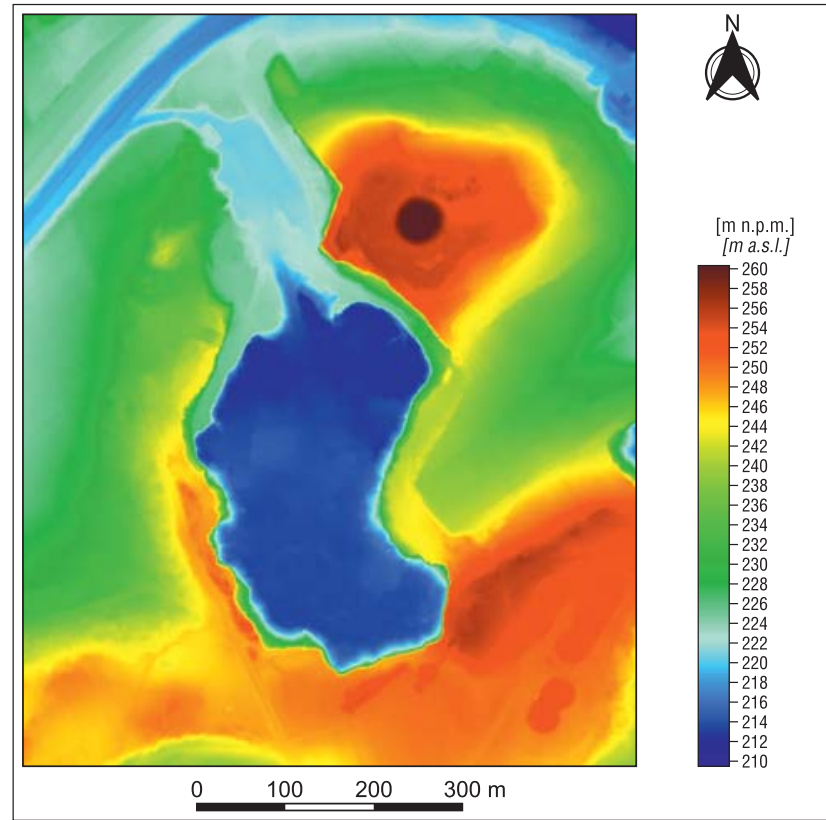

Ryc. 10. Numeryczny model terenu kamieniołomu Liban z uwzględnieniem terenów otaczających

Fig. 10. Digital elevation model of the Liban quarry including the surrounding areas

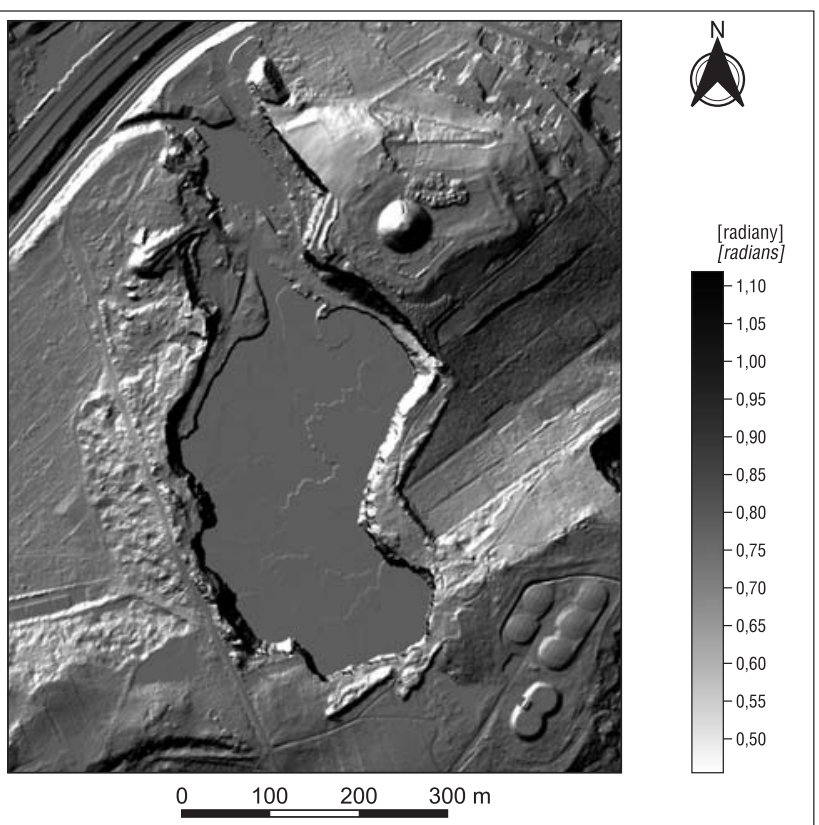

Ryc. 11. Cieniowana rzeźba terenu kamieniołomu Liban z uwzględnieniem terenów otaczających

Fig. 11. Hillshading relief of the Liban quarry including the surrounding areas

(ryc. 13). Taki rozkład kierunków nachylenia ścian powinien być uwzględniany w planach dotyczących rewitalizacji i turystycznego udostępnienia tego obszaru. Ściany o ekspozycji wschodniej i zachodniej w lepszym stopniu ukazują lokalną budowę geologiczną kamieniołomu Liban (lokalna antyklina, uskoki). Ściany skalne bez względu na ekspozycję, ale o największej wysokości względnej będą w lepszym stopniu uwidaczniały skutki współczesnych procesów geomorfologicznych. Z kolei ściany skalne o ciepłej ekspozycji - W i SW - powinny być szybciej kolonizowane przez murawy kserotermiczne (ryc. 13).

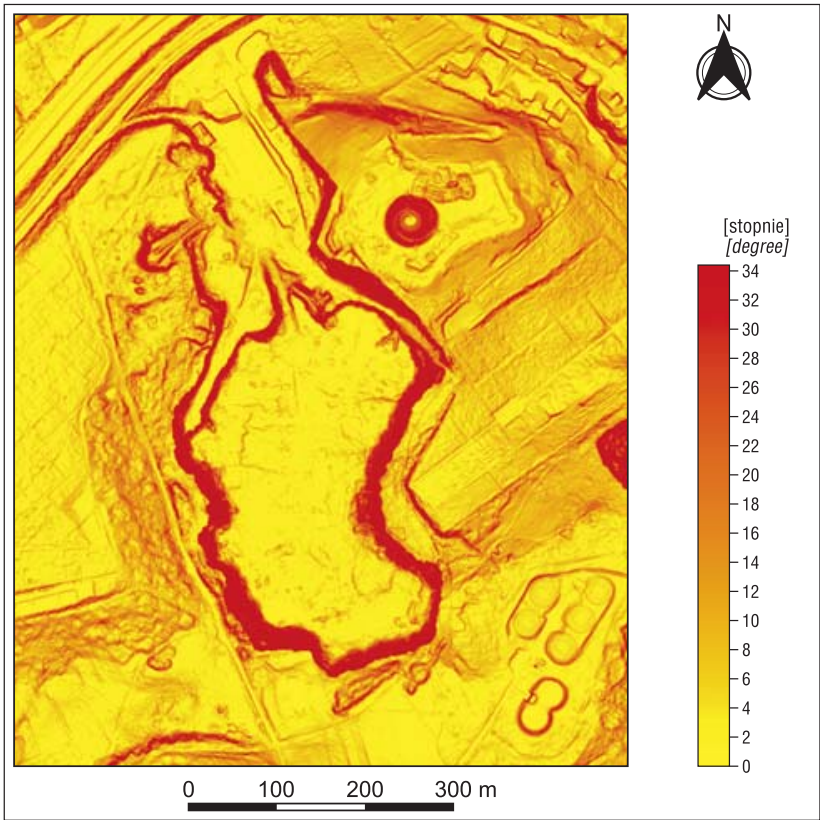

Ryc. 12. Spadki na obszarze kamieniołomu Liban z uwzględnieniem terenów otaczających

Fig. 12. Slopes in the Liban quarry and the surrounding areas

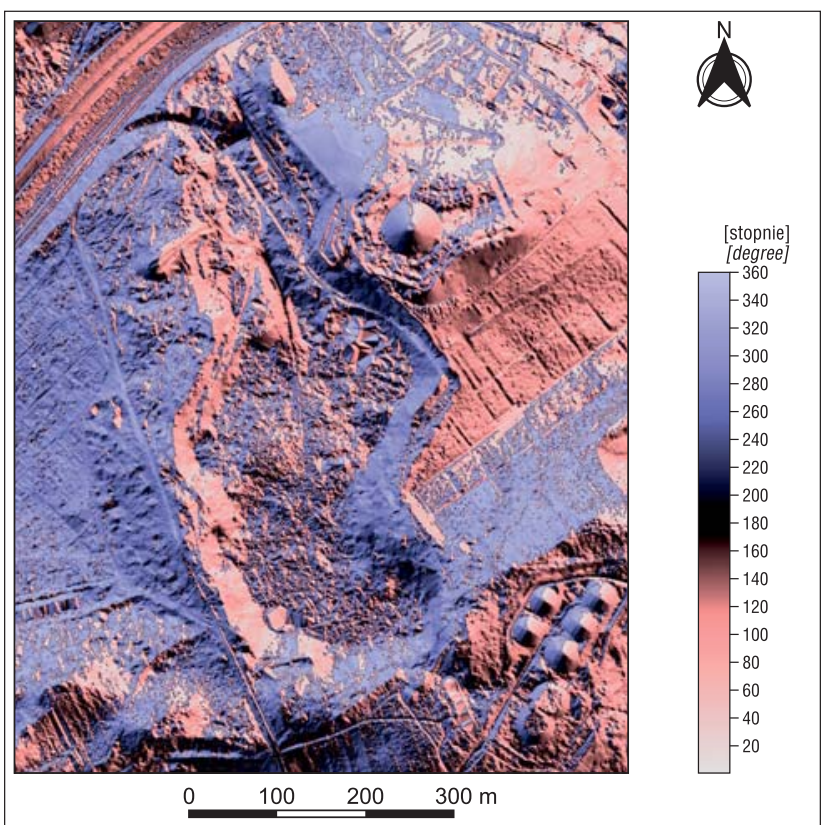

Ryc. 13. Ekspozycje stoków na obszarze kamieniołomu Liban $\mathrm{z}$ uwzględnieniem terenów otaczających

Fig. 13. Aspects of slopes in the Liban quarry and the surrounding areas

\section{WYBRANE ELEMENTY RZEŹBY WYROBISKA GÓRNICZEGO}

W obrębie dawnego kamieniołomu Liban zaznaczają się dwie główne formy terenu. Pierwszą stanowią różnej wysokości ściany skalne $\mathrm{z}$ niewielkimi występami w formie półek, a drugą płaskie dno wyrobiska górniczego.

U podnóża ścian skalnych rozwijają się formy akumulacyjne: regularne stożki usypiskowe, a także hałdy usypiskowe o podobnej wysokości lecz większym zasięgu (ryc. 14, 15, 16 - patrz str. 1020). Te ostatnie należy odróż- 


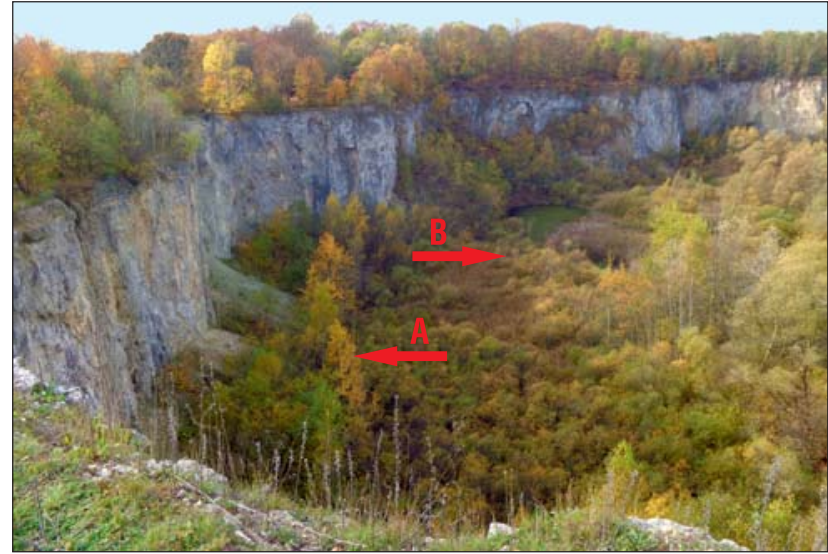

Ryc. 14. Ściana południowa i południowo-zachodnia kamieniołomu Liban. A - stożki usypiskowe; B - zbiorniki wodne (19.10.2019) Fig. 14. The southern and south-western wall of the Liban quarry. A - debris cones, B - water reservoirs (19.10.2019)

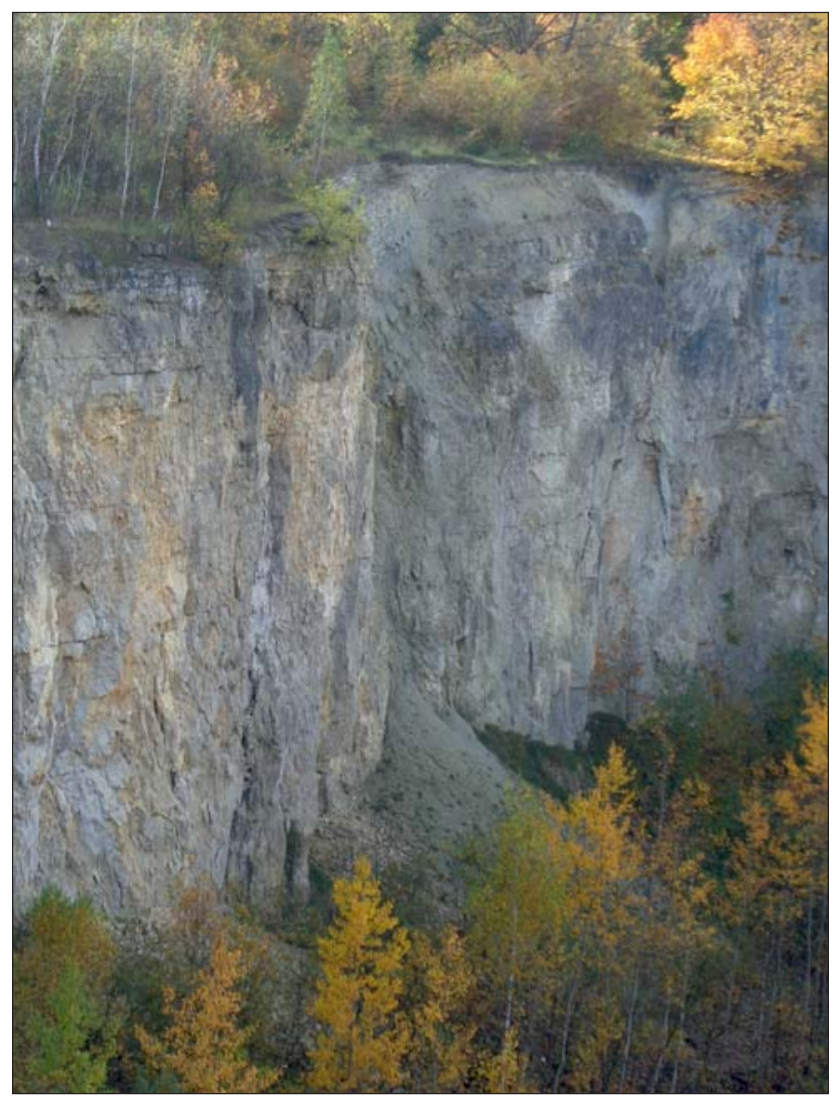

Ryc. 15. Stożek usypiskowy w kamieniołomie Liban (19.10.2019) Fig. 15. Debris cone in the Liban quarry (19.10.2019)

nić od zwałów bezużytecznego gruzu (zwanych także hałdami), zdeponowanego podczas prac eksploatacyjnych poza zasięgiem wyrobiska (ryc. 6). Hałdy usypiskowe rozwijają się poniżej formujących się, aktualnie płytkich żlebów, które rozcinają segmenty ścian o największej wysokości - głównie w części S i SW wyrobiska. Rozwój tych form akumulacyjnych jest dynamiczny i odzwierciedla duże natężenie procesów wietrzenia i odpadania na ścianach skalnych. Przeprowadzone obserwacje nie pozwalają stwierdzić, jakie są uwarunkowania geologiczne rozwoju żlebów. Pewne wskazówki dotyczące tego zagadnienia zawierają publikacje Szczepańskiej (2005a, b), w których autorka stwierdza, że w SW części wyrobiska, w ścia- nie skalnej, w końcowej fazie prac górniczych została odsłonięta kopalna studnia krasowa wypełniona osadami ilastymi i blokami wapienia. Odsłonięcie takich form może inicjować rozwój żlebów, których dalszy rozwój zachodzi już na skutek korazji ściany przez odpadający i osuwający się materiał skalny. Gruz skalny budujący hałdy i stożki składa się z różnej wielkości okruchów, najczęściej o kilkucentymetrowej średnicy, zauważalne są jednak bryły o średnicy ponad 50,0 cm. Zarówno w hałdach, jak i w stożkach widoczna jest segregacja gruzu, największe bryły są najczęściej zdeponowane w dolnej części tych form. Formujące się hałdy i stożki usypiskowe stanowią najbardziej spektakularny element rzeźby kamieniołomu, mający duże znaczenie dydaktyczne, który powinien zostać wyeksponowany w przyszłym zrewitalizowanym obiekcie.

Formy akumulacyjne rozwijające się poniżej ścian skalnych nadbudowują brzeżne partie skalnego dna wyrobiska (ryc. 8, 14, 15). W odległości kilku metrów od skraju hałd i stożków usypiskowych dno wyrobiska jest pokryte cienką warstwą rumoszu (do kilkudziesięciu centymetrów miąższości), gdzie lokalnie odsłaniają się ławice skalne.

\section{WARUNKI HYDROLOGICZNE I ŚRODOWISKO BIOTYCZNE KAMIENIOLOMU - WYBRANE INFORMACJE}

Jak podaje Jakubowski i in. (1986) poziom wodonośny w dnie kamieniołomu znajduje się średnio na wysokości 211,7 m n.p.m., czyli w segmencie B na głębokości 0,32,3 m. Z Mapy hydrograficznej w skali 1 : 50000 z 1997 r. wynika, że przepuszczalność gruntów w Libanie jest zróżnicowana, a w lokalnych depresjach istnieją warunki do trwałego stagnowania wody. Jeden ze zbiorników wodnych - zlokalizowany w południowej części odkrywki, został zaznaczony na tej mapie oraz na Mapie topograficznej w skali 1:10 000 z 1997 r. i istnieje do dzisiaj (ryc. 14, 17). Wynika z tego, że powierzchniowe zbiorniki wodne w dnie wyrobiska kamieniołomu nie mają charakteru okresowego. Bardziej szczegółowa charakterystyka tych zbiorników dotycząca m.in zmian ich zasięgu wymaga dalszych systematycznych obserwacji. Zbiorniki te należą pod względem topograficznym do bezodpływowych, gdyż są zlokalizowane w najniżej położonych obszarach kamieniołomu. Taka sytuacja sprzyja rozwojowi siedliska flory i fauny wodnej.

Dno wyrobiska w jego południowej części różni się od całego obszaru kamieniołomu pod względem warunków wodnych, gdzie podłoże z uwagi na właściwości hydrogeologiczne wapieni jest zwykle suche. Trwałe stagnowanie wody w postaci płytkich zbiorników wodnych umożliwia rozwój gatunków roślin wodnolubnych (np. trzciny, turzyce, pałki wodne). Miejsca te stanowią siedlisko ptactwa wodnego (np. kaczki krzyżówki, czernice), niektórych gatunków owadów (np. ważki, a szczególnie motyle) oraz płazów i gadów (Dawidziuk, 2009).

Z wilgotnym dnem kamieniołomu kontrastują suche ściany skalne obrzeżające wyrobisko, gdzie na półkach są spotykane murawy kserotermiczne. Miejsca te są penetrowane przez niektóre gatunki ptaków (kawki, pustułki) (Mydłowski, 2016).

\section{ZAGOSPODAROWANIE TERENU}

W 1976 r., jeszcze na etapie trwania prac wydobywczych, powstała koncepcja zagospodarowania przestrzen- 


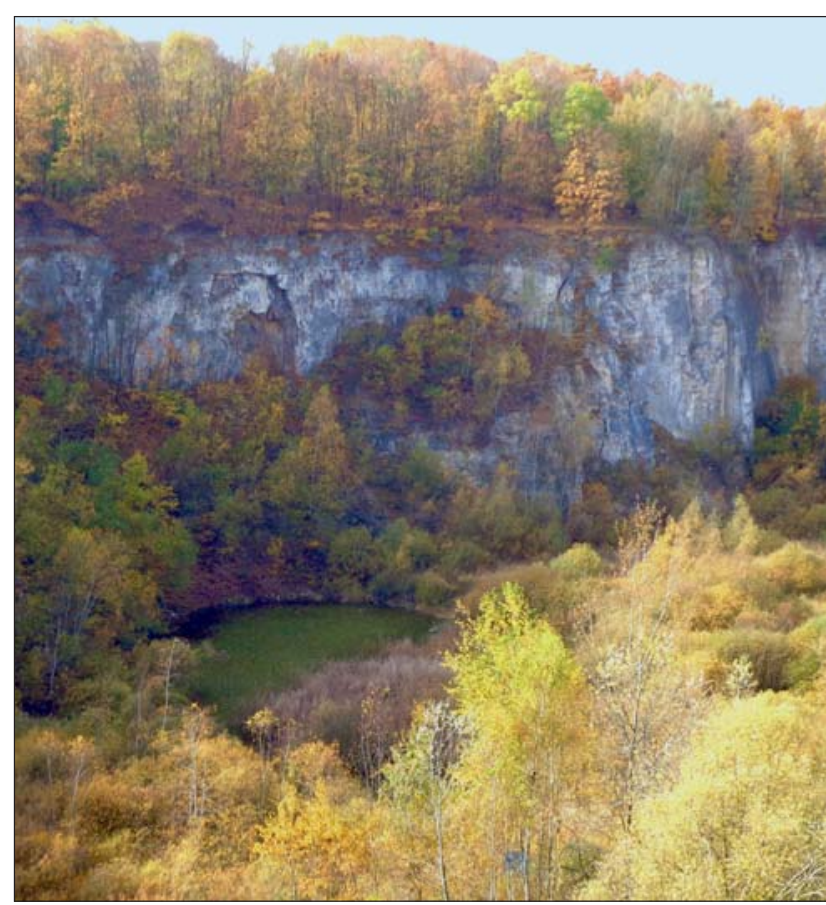

Ryc. 17. Zbiornik wodny w dnie wyrobiska (19.10.2019)

Fig. 17. Water reservoir in the bottom of the working (19.10.2019)

nego Podgórskiego Zespołu Wypoczynkowego, zgodnie z która wspomniana odkrywka miała być przystosowana do celów rekreacyjnych. $\mathrm{Na}$ obszarze zajętym przez Zakłady Wapiennicze w dnie wyrobiska miało powstać kapielisko wraz z obiektami towarzyszącymi. Planowano pogłębienie wyrobiska o 10,0 m, w związku z utworzeniem zalewu (Barburska, 1976). W latach 1988-2004 kamieniołom Liban użytkowało Przedsiębiorstwo Gospodarki Komunalnej (Górecki, Sermet, 2010). Próbę określenia kierunków rekultywacji i rewaloryzacji omawianego kamieniołomu podjęła Ostręga (2002). W późniejszych latach teren ten został przekazany Fundacji Miejskiej Centrum Edukacji Kulturowej i Ekologicznej (Wicher i in., 2003). W 2015 r. powstała praca inżynierska w formie projektu koncepcyjnego, który miał na celu utworzenie na terenie Libanu przestrzeni dla turystów, uwzględniając jego wartości przyrodnicze i sacrum (https://bukadesign.pl/projekty/rewitalizacja-kamieniolomu-liban/). Aktualnie ściana skalna El Pułkownik (30,0 m wysokości) jest udostępniona do celów wspinaczkowych.

Obecnie kamieniołom Liban znajduje się w posiadaniu Zarządu Zieleni Miejskiej w Krakowie. Na jego obszarze znajdują się pozostałości zabudowy przemysłowej, tj. zabytkowe stalowe młyny wapienne i piece do wypalania wapna (ryc. 18). Do tej pory zachowane są także niektóre fragmenty inscenizacji filmu Stevena Spielberga z 1993 r. pt. Lista Schindlera (Górecki, Sermet, 2010). Są to np. kopie macew, którymi jest wyłożona droga na dnie kamieniołomu.

Pomimo zakończonej ponad 30 lat temu eksploatacji kamieniołom nadal nie został zrekultywowany ani zagospodarowany. Niemniej jednak jest uznawany za unikatowe, a zarazem tajemnicze miejsce, nie tylko z uwagi na zachowane do dziś elementy dziedzictwa historycznego i filmowego, ale również ze względu na geo- oraz bioróżnorodność. Chociaż wstęp na jego teren jest zabroniony, często można spotkać grupy ludzi, którzy chcą spędzić wolny czas w niestandardowym miejscu. Sprzyja temu również fakt położenia kamieniołomu Libanu w bliskiej odległości od centrum Krakowa, dobra komunikacja oraz możliwość nielegalnego wejścia na teren odkrywki. Ten ostatni aspekt jest szczególnie cenny dla tych, którzy poszukują dodatkowej dawki adrenaliny. Jednakże należy pamiętać, że Liban jest terenem niezabezpieczonym, a tym samym niebezpiecznym, zwłaszcza gdy bierze się pod uwagę możliwość swobodnego spacerowania wzdłuż krawędzi ścian skalnych wokół wyrobiska. Odpowiednie działania rewitalizacyjne $z$ pewnością pozwoliłyby na odwiedzanie tego obiektu w bezpieczny sposób. Niemniej jednak rewitalizacja powinna zostać przeprowadzona tak, aby dziedzictwo przyrodnicze, historyczne i kulturowe zostało zachowane.

Pierwsze prace rewitalizacyjne mają zostać rozpoczęte w 2020 r. (https://podroze.onet.pl/ciekawe/kamieniolomliban-to-opuszczone-miejsce-w-krakowie-skrytych-jest- w-nimwiele-rzeczy/yql6css). Będą one realizowane w ramach projektu przygotowywanego przez kilkanaście lat, na który miasto otrzymało dofinansowanie (http://krakow.pl/ aktualnosci/232653,29,komunikat,kamieniolom liban_czeka_rewitalizacja.html). Na przełomie 2021 i $20 \overline{2} 2$ r. w dzisiejszym kamieniołomie Liban powstanie park rekreacyjno-sportowy (Mrowiec, Dybała, 2019). Jak wynika z podanych informacji, cenne pod względem geologicznym, geomorfologicznym oraz botanicznym fragmenty wyrobiska kamieniołomu Liban zostaną właściwie zabezpieczone (http://krakow.pl/aktu-alnosci/232653,29,komunikat,kamieniolom liban czeka rewitalizacja.html). Część zachowanych budynków będzie poddana pracom remontowym (np. dawna sztygarówka), pozostałe ulegną rozbiórce. Planowane jest także stworzenie ścianek wspinaczkowych itp. (Mrowiec, Dybała, 2019).

Bez względu na to, w jaki sposób zostaną zrealizowane plany rewitalizacji kamieniołomu Liban, przed wejściem na jego obszar powinny zostać w widocznych miejscach umieszczone tablice informujące o historii powstania kamieniołomu oraz o istniejącym w tym miejscu podczas okupacji niemieckiej Obozie Służby Budowlanej (Baudienst). W dnie wyrobiska należałoby umieścić tablice informujące o bio- i georóżnorodności tego miejsca oraz elementach kulturowych. Istniejące zbiorniki wodne powinny zostać zabezpieczone $\mathrm{z}$ uwagi na florę i faunę tutaj występująca, a ściany skalne jedynie częściowo zagospodarowane i wykorzystane do celów wspinaczkowych. W dnie wyrobiska

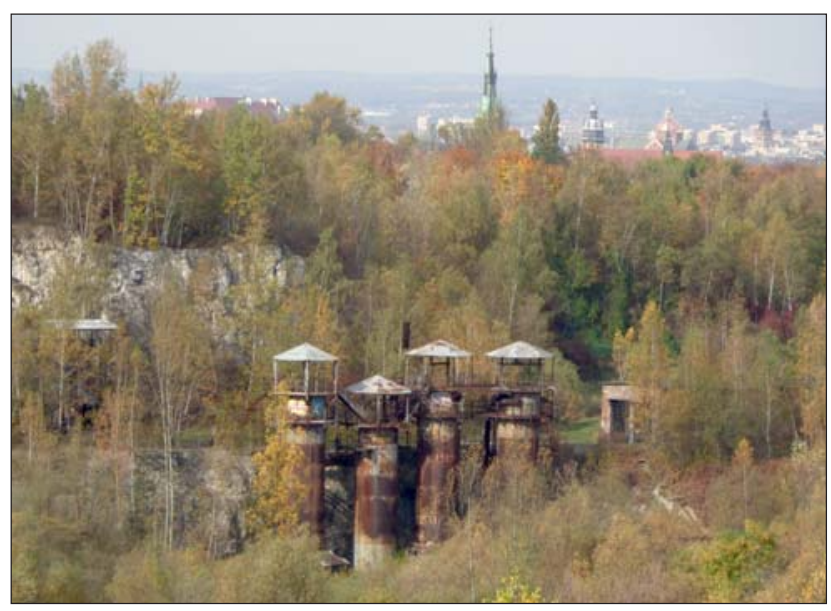

Ryc. 18. Pozostałości zabudowy przemysłowej w kamieniołomie Liban, na dalszym planie Stare Miasto (19.10.2019)

Fig. 18. Remnants of industrial development in the Liban quarry, Old Town in the background (19.10.2019) 
mogłyby powstać ścieżki dydaktyczne, które sprzyjałyby rozwojowi funkcji poznawczej. Na właściwie zlokalizowanych przystankach takich ścieżek powinny znaleźć się tablice $\mathrm{z}$ informacjami m.in. o dynamicznym rozwoju ścian skalnych, gdyż obserwowane modelowanie stożków i hałd usypiskowych stanowi unikalną sytuację (oprócz kamieniołomu Zakrzówek) na terenie miasta Krakowa.

\section{PODSUMOWANIE}

Górnictwo odkrywkowe na terenie dawnego kamieniołomu Liban w Krakowie spowodowało w skali lokalnej nieodwracalne zmiany w topografii terenu. Utworzone w wyniku działalności górniczej ściany skalne oraz rozległa podłoga skalna w dnie wyrobiska stanowią urozmaicenie morfologii tego obszaru, który wyróżnia się na terenie Krakowa pod względem atrakcyjności z punktu widzenia turystyki i rekreacji, a także niektórych aspektów przyrody ożywionej. Ściany skalne modelowane przez procesy geomorfologiczne stanowią żywe laboratorium przyrody, które może stanowić cel wycieczek na różnych poziomach edukacji. Podobnie duże zainteresowanie wzbudza sukcesja roślinności na jeszcze niedawno odsłoniętych powierzchniach skalnych (pionowych, gdzie wkraczają murawy kserotermiczne, oraz poziomych - w niektórych miejscach zasiedliły się rośliny preferujące siedliska wodne). Udostępnienie złoża rozległym wyrobiskiem ujawniło georóżnorodność omawianego obszaru, z kolei samoistnie zachodząca rekultywacja przyczynia się do wzrostu bioróżnorodności, co niewątpliwie podnosi walory tego terenu pogórniczego.

Pozostaje mieć nadzieję, że planowana rewitalizacja kamieniołomu Liban przyczyni się do powstania atrakcyjnego miejsca pod względem turystycznym i rekreacyjnym, ale w taki sposób, aby zachowane zostały jego unikatowe walory przyrodnicze, a także pamięć historyczna.

Autorka składa serdeczne podziękowania recenzentom: pani dr hab. prof. PIG-PIB Barbarze Radwanek-Bąk oraz anonimowemu Recenzentowi, za wnikliwe recenzje, cenne uwagi i wskazówki, a także panu dr. hab. prof. PAN Janowi Urbanowi za udostępnienie literatury naukowej i prof. dr. hab. Adamowi Łajczakowi za dyskusję nad problematyką artykułu.

\section{LITERATURA}

BARBURSKA G. 1976 - Zagospodarowanie terenu Wapiennika „Liban” w Krakowie. Propozycje rozwiązania przestrzennego. Biuro Projektów Budownictwa Komunalnego w Krakowie, Krakowskie Zakłady Przemysłu Wapienniczego, Kraków.

BOBEK W., KUMAŃSKA-DZIÓB E. 2018 - Różnice w sukcesji drzewostanu W zależności od sposobu zagospodarowania terenu na przykładzie Parku Bednarskiego i Kamieniołomu Libana w Krakowie. [W:] Gawryszewska B.J., Giedych R. (red.), XXI Forum Architektury Krajobrazu 27-29.09.2018 SGGW w Warszawie, książka abstraktów. P.W. Polimax P. Kacprzak, R. Suława - S.C., Warszawa: 82.

DAWIDZIUK L. 2009 - Kamieniołom Libana. http://podgorze.pl/kamieniolom-libana/ (dostęp: 15.11.2019).

DOLEGŁO M. 2011 - Przyrodnicze i historyczne uwarunkowania rozwoju krakowskiego Podgórza jako czynniki rewitalizacji. Przestrzeń i Forma, 15: 391-412.

DUBIEL E., GAWROŃSKI S. 2005 - Zbiorowiska roślinne Krzemionek Podgórskich. [W:] Szczepańska M., Pilecka E. (red.), Geologiczno-przyrodnicze rozpoznanie terenów pogórniczych Krzemionek Podgórskich dla potrzeb ochrony ich wartości naukowo-dydaktycznych i ekologicznych. Wyd. IGSMiE PAN, Kraków: 101-109.

GAWROŃSKI S. 2005 - Ssaki Krzemionek Podgórskich. [W:] Szczepańska M., Pilecka E. (red.), Geologiczno-przyrodnicze rozpoznanie terenów pogórniczych Krzemionek Podgórskich dla potrzeb ochrony ich wartości naukowo-dydaktycznych i ekologicznych. Wyd. IGSMiE PAN, Kraków: 122
GLINIAK M. 2012 - Projekt rewitalizacji miejskich terenów pogórniczych na przykładzie kamieniołomu „Liban” w Krakowie. [W:] Kuczera M. (red.), Młodzi naukowcy dla Polskiej Nauki, Nauki Przyrodnicze. Creativetime, Kraków, 8 (4): 137-141.

GLINIAK M. 2015 - 'Liban' Quarry - education path promoting conservation traces of former opencast mining. Inżynieria Mineralna, 16 (1): 121-126.

GÓRECKI J., SERMET E. 2010 - Kamieniołomy Krakowa - dziedzictwo niedocenione. [W:] Zagożdżon P.P, Madziarz M. (red.), Dzieje górnictwaelement europejskiego dziedzictwa kultury. Wrocław, 3: 131-133.

GRADZIŃSKI R. 1972 - Przewodnik geologiczny po okolicach Krakowa. Wyd. Geol., Warszawa.

GUZIK J., PACYNA A. 2005 - Flora roślin naczyniowych Krzemionek Podgórskich. [W:] Szczepańska M., Pilecka E. (red.), Geologiczno-przyrodnicze rozpoznanie terenów pogórniczych Krzemionek Podgórskich dla potrzeb ochrony ich wartości naukowo-dydaktycznych i ekologicznych. Wyd. IGSMiE PAN, Kraków: 87-100.

http://krakow.pl/aktualnosci/232653,29,komunikat,kamieniolom_liban_czeka_rewitalizacja.html (dostęp 15.11.2019)

http://podgorze.pl/wp-content/uploads/2011/09/3-2.jpg (dostęp 15.11.2019). https://bukadesign.pl/projekty/rewitalizacja-kamieniolomu-liban/ (dostęp 15.11.2019).

https://podroze.onet.pl/ciekawe/kamieniolom-liban-to-opuszczone-miejsce -w-krakowie-skrytych-jest-w-nim-wiele-rzeczy/yql6css(dostęp 15.11.2019). JAKUBOWICZ W., OSTROWSKA-GILL B., PIĘKOŚ L. 1987 - Wniosek o zniesienie obszaru górniczego „Krzemionki” dla złoża wapienia. Biuro Projektów Przemysłu Cementowego, Wapienniczego i Gipsowego „Biprocemwap” w Krakowie, Ministerstwo Budownictwa, Gospodarki Przestrzennej i Komunalnej w Warszawie, Cementownia "Nowa Huta” w Krakowie, Kopalnia Wapienia „Za Torem” w Krakowie, Kraków.

JAKUBOWSKI K., KAJZER-BONK J. 2017 - Nieużytki i... nowa przyroda miasta. [W:] Jakubowski K., Kajzer-Bonk J., Oswajamy przyrodę miasta i okolic. Przewodnik REFA po ścieżkach edukacyjno-przyrodniczych. Rodzinne spacery edukacyjne po nieużytkach i dzikiej przyrodzie. Ruch Ekologiczny św. Franciszka z Asyżu (REFA). WFOŚiGP, Kraków: 22-23.

KASZTELEWICZ Z. 2010 - Przykłady rekultywacji i zagospodarowania terenów pogórniczych w czynnych kopalniach odkrywkowych w Polsce. [W:] Kasztelewicz Z., Rekultywacja terenów pogórniczych w polskich kopalniach odkrywkowych. Monografia. Fundacja Nauka i Tradycje Górnicze z siedzibą Wydz. Górnictwa i Geoinżynierii AGH im. S. Staszica, Kraków: 66-67.

KOTOŃSKA B. 2005 - Waloryzacja i postulaty ochronne przyrody ożywionej. [W:] Szczepańska M., Pilecka E. (red.), Geologiczno-przyrodnicze rozpoznanie terenów pogórniczych Krzemionek Podgórskich dla potrzeb ochrony ich wartości naukowo-dydaktycznych i ekologicznych. Wyd. IGSMiE PAN, Kraków: 123-127.

MAJER-DURMAN A. 2012 - The occurrence of Upper Jurassic limestones in Cracow area and examples of their usage in the city architecture. Geoturystyka, 1-2 (28-29): 13-22.

MAPA HYDROGRAFICZNA w skali $1: 50 \quad 000$ (1997), ark. Kraków-Zach. OPGK Białystok.

MAPA TOPOGARFICZNA w skali 1: $10 \quad 000 \quad$ (1997), ark. Kraków-Wola Duchacka. OPGK-Rzeszów S.A.

MROWIEC M., DYBAŁA B. 2019 - Gigantyczna inwestycja. Duże zmiany w słynnym kamieniołomie. https://krakow.naszemiasto.pl/gigantyczna-inwestycja-duze-zmiany-w-slynnym-kamieniolomie/ar/c17278973 (dostęp: 15.11.2019)

MYDŁOWSKI M. 2016 - Proponowany użytek ekologiczny „Kamieniołom Liban”. [W:] Kierunki rozwoju i zarządzania terenami zielonymi w Krakowie na lata 2017-2030, Aneks II: Ochrona przyrody. Kraków: 116-119.

OSTRĘGA A. 2001 - Zagospodarowanie kamieniołomu Libana z uwzględnieniem jego losów wojennych oraz sąsiedztwa terenu byłego KL „Płaszów”. Górn. Odkryw., 43 (6): 51-60.

OSTRĘGA A. 2002 - Zagospodarowanie kamieniołomu Libana. Aura, 5: $19-22$.

RAJCHEL J. 2005 - Kamienny Kraków. Spojrzenie geologa. AGH Uczelniane Wyd. Naukowo-Dydaktyczne, Kraków.

RUTKOWSKI J. 1992 - Szczegółowa Mapa Geologiczna Polski w skali $1: 50$ 000, ark. 973 - Kraków. Wydaw. Geol., Warszawa.

RUTKOWSKI J. 1986 - O trzeciorzędowej tektonice uskokowej okolic Krakowa. Prz. Geol., 34 (10): 587-590.

RUTKOWSKI J. 1993 - Objaśnienia do Szczegółowej Mapy Geologicznej Polski 1 : 50 000, ark. 973 - Kraków. Państw. Inst. Geol., Warszawa. SALWIŃSKI J. (red.) 2004 - Podgórze. Przewodnik po Podgórzu, prawobrzeżnej części Krakowa. vis-à-vis etiuda, Kraków: 64-65.

SOLON J., BORZYSZKOWSKI J., BIDŁASIK M., RICHLING A., BADORA K., BALON J., BRZEZIŃSKA-WÓJCIK T., CHABUDZIŃSKI Ł, DOBROWOLSKI R., GRZEGORCZYK I, JODŁOWSKI M., KISTOWSKI M., KOT R., KRĄŻ P., LECHNIO J., MACIAS A., 
MAJCHROWSKA A., MALINOWSKA E., MIGOŃ P., MYGA-PIĄTEK U., NITA J., PAPIŃSKA E., RODZIK J., STRZYŻ M., TERPIŁOWSKI S., ZIAJA W. 2018 - Physico-geographical mesoregions of Poland: Verfication and adjustment of boundaries on the basis of contemporary spatial data. Geograph. Pol., 91(2): 143-170.

SZCZEPAŃSKA M. 2005a - Kamieniołomy Krzemionek Podgórskich charakterystyka geologiczna. [W:] Żółciak J. (red.), W 90. rocznice połączenia Podgórza i Krakowa. Materiały VI Sesji Podgórskiej. Dom Kultury „Podgórze”, Kraków: 44-47.

SZCZEPAŃSKA M. 2005b - Kamieniołom Liban. [W:] Szczepańska M., Pilecka E. (red.), Geologiczno-przyrodnicze rozpoznanie terenów pogórniczych Krzemionek Podgórskich dla potrzeb ochrony ich wartości naukowo-dydaktycznych i ekologicznych. Wyd. IGSMiE PAN, Kraków: 48-49.

TYCZYŃSKA M. 1968a - Rzeźba i budowa geologiczna terytorium miasta Krakowa.[W:] Środowisko geograficzne terytorium miasta Krakowa. PAN, Komisja Nauk Geogr., Kraków, 1: 9-34.

TYCZYŃSKA M. 1968b - Rozwój geomorfologiczny terytorium miasta Krakowa. Zesz. Nauk. UJ, Pr. Geograf., Kraków, 17: 5-68.

TYCZYŃSKA M., CHMIELOWIEC S. 1988 - Mapa geomorfologiczna Krakowa (9). [W:] Trafas K., Hess M., Atlas miasta Krakowa. PPWK, Warszawa-Wrocław.

TYROWICZ T. 1977 - Kamień w zabytkach średniowiecznego Krakowa. Bibl. Jagiell., Kraków (niepubl.).

WALASZ K. 2005 - Awifauna legowa Krzemionek Podgórskich. [W:] Szczepańska M., Pilecka E. (red.), Geologiczno-przyrodnicze rozpoznanie terenów pogórniczych Krzemionek Podgórskich dla potrzeb ochrony ich wartości naukowo-dydaktycznych i ekologicznych. Wyd. IGSMiE PAN, Kraków: 117-121.

WALENDOWSKI H. 2005 - Zagospodarowanie terenów poeksploatacyjnych. Nowy Kamieniarz, 17: 40-42.
WICHER E., OSTRĘGA A., JACHIMCZAK M. 2003 - Centrum Edukacji Kulturowej i Geologicznej na Krzemionkach Podgórskich w Krakowie. [W:] Środulska-Wielgus J., Wielgus K., Panek R., Kształtowanie krajobrazu terenów poeksploatacyjnych w górnictwie. Międzynar. Konf. Nauk., Kraków 10-12 grudnia 2003. Biuro Usług Komputerowych Stanisław Smaga, Dębica, Kraków: 285-295.

WIELGUS K., ŚRODULSKA-WIELGUS J. 2003 - Zarys zasad rejestracji zintegrowanej: postaci, wartości i przemian krajobrazów inżynieryjnych. $\mathrm{Z}$ doświadczeń dydaktycznych i projektowych, dotyczących wyrobisk poeksploatacyjnych w górnictwie skalnym. [W:] Środulska-Wielgus J., Wielgus K., Panek R., Kształtowanie krajobrazu terenów poeksploatacyjnych w górnictwie. Międzynar. Konf. Nauk., Kraków 10-12 grudnia 2003. Biuro Usług Komputerowych Stanisław Smaga, Dębica, Kraków: $112-139$.

WITEK A., STAREK K., GŁOWACKA M., ŁUGAWIAK M., BARANOWSKI M., PTAK W. 2014 - Miejski Program Rewitalizacji Krakowa. Aktualizacja. Urząd Miasta Krakowa, Wydział Rozwoju Miasta, Lider Projekt Sp. z o.o., Kraków, Poznań.

WROŃSKI T. 1981 - „Liban” - karny obóz Służby Budowlanej w Krakowie w latach 1942-1944. Wyd. „Sport i turystyka”, Warszawa.

ZARYCHTA R. 2018 - Geostatystyczna wizualizacja rzeźby terenu kamieniołomu „Liban”. [W:] Adamiec-Wójcik I. (red.), XX Konferencja Naukowo-Techniczna „Zapobieganie zanieczyszczeniu, przekształcaniu i degradacji środowiska". Szczyrk, 29-30 listopada 2018 r. Streszczenia prezentacji. Wyd. Naukowe ATH, Bielsko-Biała: 92.

ZYŚK B. 2005 - Herpetofauna okolic rezerwatu Bonarka i kamieniołomu Liban. [W:] Szczepańska M., Pilecka E. (red.), Geologiczno-przyrodnicze rozpoznanie terenów pogórniczych Krzemionek Podgórskich dla potrzeb ochrony ich wartości naukowo-dydaktycznych i ekologicznych. Wyd. IGSMiE PAN, Kraków: 117.

Praca wpłynęła do redakcji 16.09.2019 r.

Akceptowano do druku 4.10.2019 r. 
Krajobraz poeksploatacyjny kamieniolomu Liban w Krakowie - patrz str. 1002 The post-mining landscape of the Liban quarry in Cracow - see p. 1002

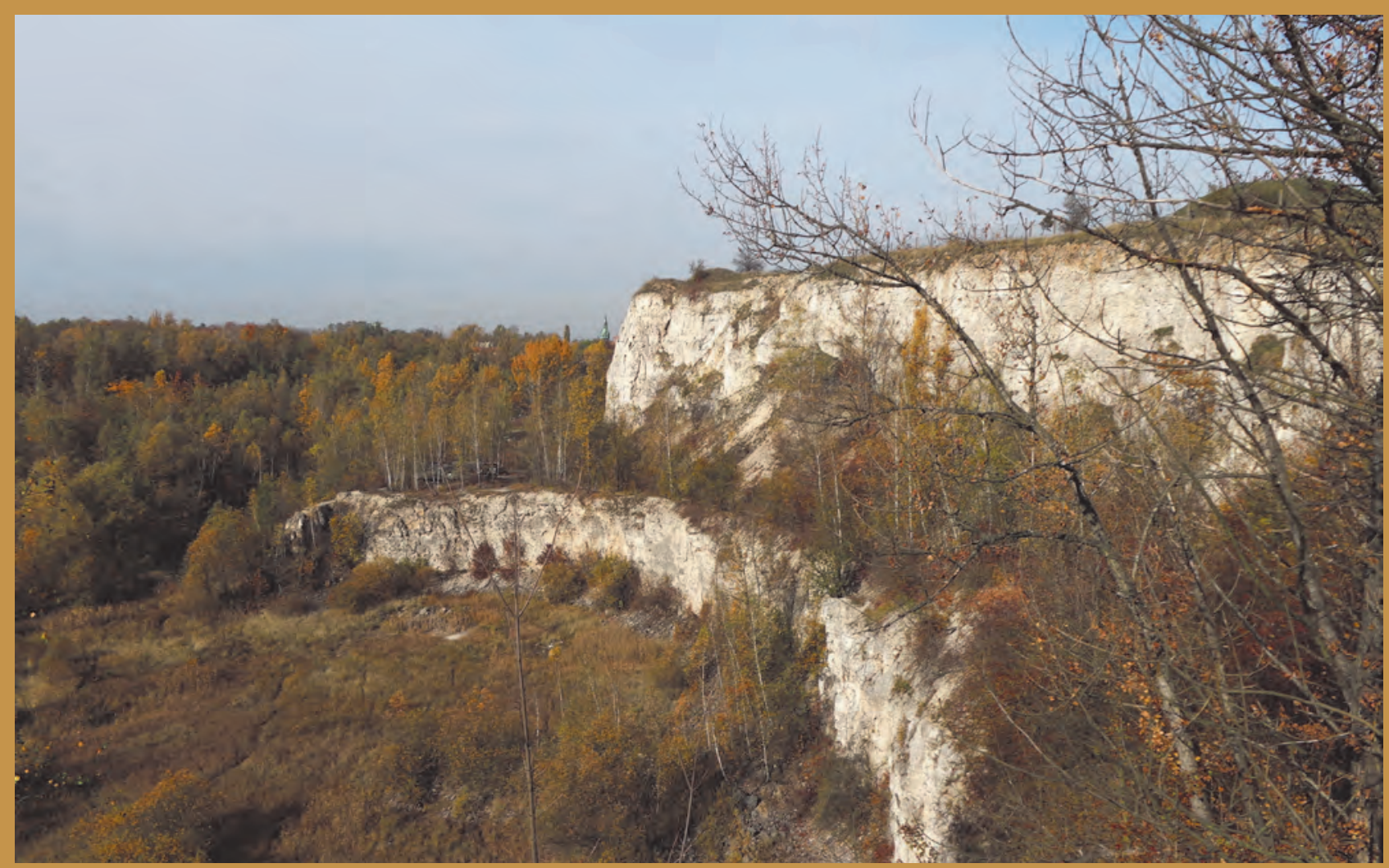

Ryc. 8. Widok na dwa poziomy wyrobiska w północno-wschodniej części kamieniołomu Liban, na kulminacji wzniesienia Kopiec Kraka (19.10.2019)

Fig. 8. The view of two working floors in the in the north-eastern part of the Liban quarry, Krak Mound on the summit (19.10.2019)

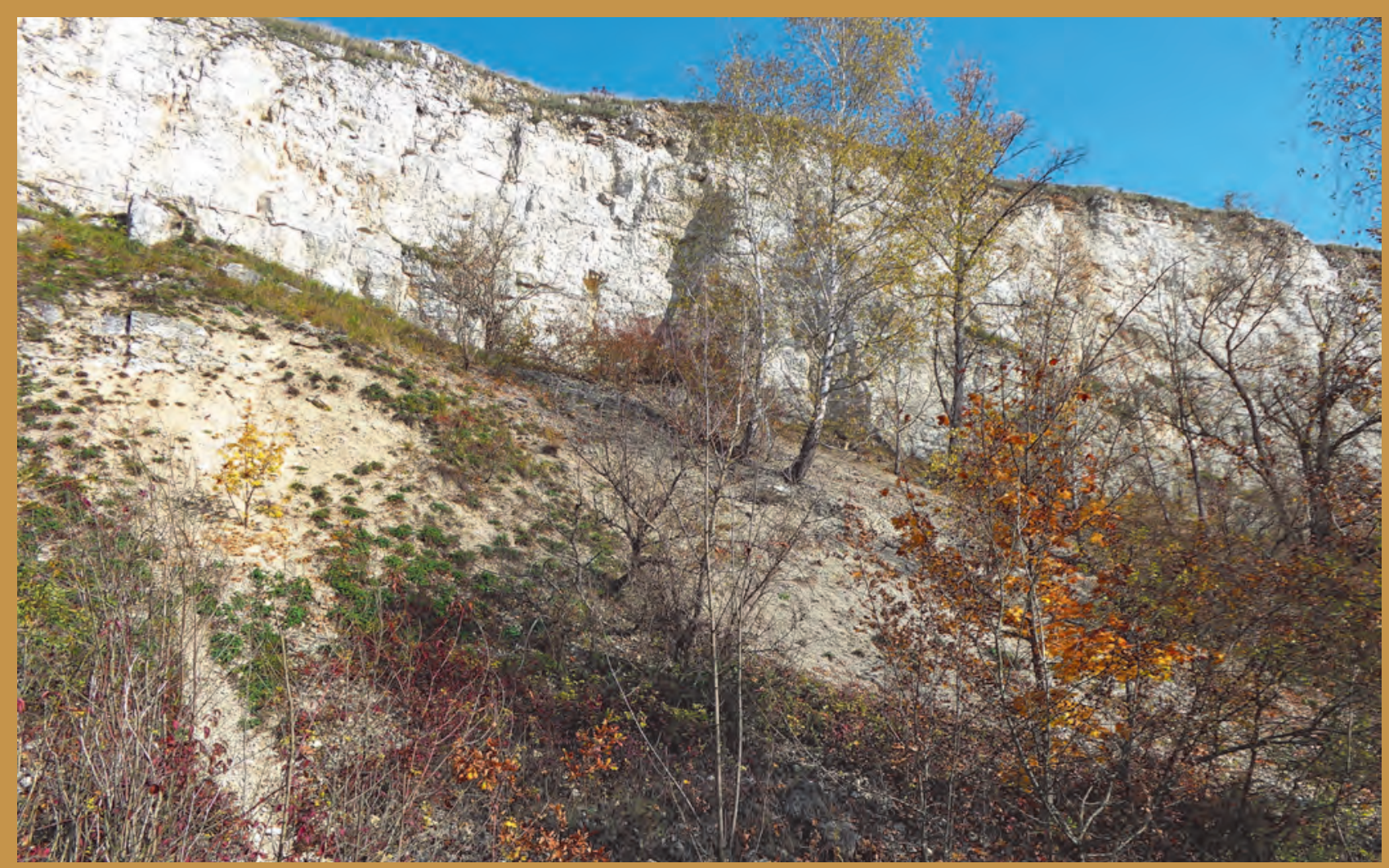

Ryc. 16. Hałda usypiskowa w kamieniołomie Liban (19.10.2019)

Fig. 16. Debris heap in the Liban quarry (19.10.2019) 